\title{
「感性とロボット」 特集について
}

感性とロボットという特集号を刊行するにあたってご挨 拶いたします。

この特集号の趣旨は,「感性」と「ロボットの研究開発」 というキーワードの両者の接点を模索することを主として いる. そしてロボットの機能に「感性」という重要な機能 を取り込むことによって，最終的に「感性を持つロボット」 の存在の可能性について考察する題材を提供しょうとする ことである.

「感性」という言葉は，広辞苑によると「(1)外界の刺激 に応じて感覚・知覚を生ずる感覚器官の感受性. (2)感覚に よってよび起こされ，それに支配される体験。従って，感 覚に伴う感情や衝動・欲望をも含む。（3理性によって制御 されるべき感覚的欲望. Sensibility (英), Sinnlichkeit(独)」 とある.この言葉の定義をそのまま受け入れることとする と, 感受性, 感情, 衝動や欲望といった客観的な取り扱い が困難な機能が直ちに想起され，「感性を持つロボット」の 研究開発の困難さが浮き彫りとなる. また英訳としてSensibility という言葉は,「感性」という日本の言葉と異なる との意見があり，直接 KANSEI というローマ字表記が使 われることが多くなってきている，私は，KANSEIなる 言葉が通じない場合，英語で Feelings あるいは Feelings with mind と言っているが，これも正しいとは言えないで あろう。

「感性」という言葉に近い, 私たちの直接的な感じは, 美しい絵画を鑑賞したときや，やさしい気持ちにさせてく れる詩に出会ったとき，あるいは実在感のある彫刻に感動 するときに，その「感性」と言う言葉の存在に気付くであ ろう。また建築物，あるいは都市の景観や自然の美しさに 感動することもある。

このような美的感動といった「感性」は，もともと主観 的であり，すなわちパーソナルな存在であって科学的記述 の困難さは想像を絶するものがある.

しかしながら，歴史的には絵画における黄金分割の美し さは有名であるし，ギリシアのアテネ市にあるパルテノン 神殿の美しさが多くの人々の支持を受けていることも事実 である．その証拠に，世界中にパルテノン神殿の複製が, それも大学や美術館のファサードに用いられていることが あげられる. 外見の完全な複製は，パリのマドレーヌ寺院
が有名であるが，完全な複製であるにもかかわらず，その 美しさには疑問が呈された。この問題はその後, 再度精密 な計測が行われ，アテネのパルテノン神殿の持つ重厚さや 尊厳さといった感性に関する科学的根拠が検討されたこと は有名である。

すなわち，いままで「感性」に関する評価は全く顧みら れなかったが，少しずつ科学的に解明されてきている事実 を無視することができなくなってきている.

とはいえ，「感性」と「ロボット」との距離はいまだ遠 くその将来は見えないとも感じられる.

しかしながら，「人間」と「機械」との関係がいかなる ようになろうとも，機械が人間にとって有用であるために は. いままでのように「人間」が「機械」に近づく関係で あるよりも，「機械」が「人間」に近づく関係であるべき であることは明白であると考える。「機械」が「人間」に 近づくためには機械が人間を理解することが是非とも必要 となる。この技術は「マンマシンインターフェース」とし て研究が進められているが「感性」の研究が, この研究方 向に位置するとともにさらに一歩前方に踏み込んでいるこ とは明らかである，たとえば，人間型の病人介護ロボット を考えた場合, 病人は単に処理すべき対象物のみにあらず, 病人の痛みや気持を感じながら介護できる必要があろう。 これは病人の「感性」を理解する必要性に言及しているの である.

本特集号は，「感性」と「ロボット」に関する最新の研 究成果を集めている，構成は，最初が「ロボットと感性」 に関する総説である，ついで，「ロボットは感性を持ちえ るか？」そして，最後は「ロボットが人間の感性に与える 影響は？」である.

今世紀は,「人間の知能」を解明する世紀であったと言 っても言い過ぎではあるまい. 知能の解明はもちろんいま だ未完であるが，多くの謎を解いてきたといえる．次世紀 は「感性」や「情感」を解明する世紀であると信じて止ま ない，なぜなら人間は人間の「知・感・情」を理解せずに はいられないであろうから.

最後に, 御多忙の中, 執筆をいただいた筆者の皆様に感 謝をいたしまして，ご挨拶を終ります。

（武野純一 明治大学） 